\title{
Analysis of Improving The Service Quality of Professional Cooperation in "XZY" Higher Education Based on Servqual, IPA and QFD
}

\author{
Muhammad Chusaeni ${ }^{1}$, Bambang Syairuddin ${ }^{2}$, and I Ketut Gunarta ${ }^{2}$ \\ ${ }^{1}$ Departement of Management Technology, Institut Teknologi Sepuluh Nopember (ITS), Surabaya \\ ${ }^{2}$ Departement of Industrial Engineering, Institut Teknologi Sepuluh Nopember (ITS), Surabaya \\ e-mail:mchus43n1@gmail.com
}

\begin{abstract}
The Status of Legal Entity State Higher Education (PTN-BH) at the Institut Teknologi Sepuluh Nopember (ITS) gives full autonomy to the management of higher education. For ITS to be able to innovate in exploring revenue generators, Business Development and Management Agency (BPPU) was formed which functions to raise, manage funds, and develop business units. Professional cooperation as one of the most dominant ITS business unit in contributing ITS revenue. BPPU as the administrative center for professional cooperation services always try to provide excellent service, but there are still complaints about these services related to speed and accuracy. To analyze the level of quality of professional cooperation services, this research uses the Servqual, ImportancePerformance Analysis (IPA) and Quality Function Deployment (QFD) methods. Servqual is used to analyze the gap between perception and customer expectations. The IPA method is used to measure the performance satisfaction expected and received by customers. And the QFD method is used to design priority strategies for improving service quality according to customer desires and technical capabilities by internal managers of professional cooperation. Servqual analysis results show the greatest gap between the perception variable and customer expectations, namely Em1 (understanding specific needs), Em2 (clarity of procedure), Rs2 (responsive service capability), and As3 (accuracy of cooperation services management). The results of the IPA analysis show that the variables in the quadrant $A$ are the same as the results of Servqual Analysis which also have high priority to be handled, namely Em1, Em2, Rs2, and As3. In QFD analysis, these variables become customer requirements (whats) associated with technical responses (hows) obtained from internal BPPU management, and according to the house of quality diagram, the priority sequence of technical response is obtained, the priority of the technical response can be applied internally by BPPU so that FGDs are carried out, with the hope that a strategy for improving service quality can reduce complaints from professional cooperation customers.
\end{abstract}

Keywords-Servqual, Importance-Performance Analysis (IPA), Quality Function Deployment (QFD), Service Quality, the Customer.

\section{INTRODUCTION}

$\mathrm{H}^{\prime}$ IGHER education is one of the significant pillars of building a nation. The implementation of education nowadays, therefore, is expected to provide high-quality service to its customers. Academic institutions are required to have continuous innovations, diverse structures, as well as discover new techniques on delivering effective service to their customers [1]. It is intended to get competitive benefits when compared to other academic institutions. One of many ways is by better understanding customer satisfaction and perceptions about service quality. Not only do modern higher education institutions deliver academic services to their students, but they also play active roles in research and community services needed by regional governments (district, city and province governments), central government, state companies (BUMN), regional companies (BUMD), as well as private companies/ institutions.

After upgrading its status to become legal entity of state higher education (PTN-BH), Institut Teknologi Sepuluh Nopember (ITS) has more independence, or full authority, to its financial management, so that the state higher education has maximum capacity to conduct Tridharma Perguruan Tinggi, a set of visions that all higher education institutions need to achieve; the visions include research and development as well as community service. By acquiring this upgraded status, ITS independently manage their budget, while Central Government regularly supplies additional budget and operational assistance. In the light of this, ITS must be able to explore innovative ideas on revenue generator sources to meet PTN-BH budgetary needs.

In order to support the above, ITS constitutes Business Development and Management Agency (BPPU) whose function is as a revenue generator to ITS and as a fundraiser, financial manager, and business unit developer. In carrying out these functions, BPPU has 4 (four) business sectors, namely Commercial Business, Supporting Business, Professional Collaboration, and Asset Collaboration.

For 3 (three) years since BPPU was constituted, the organization has been earning revenue achievement on those 4 (four) business sectors. Professional Collaboration contributes the most tax revenue (locally known as NonPNBP) compared to other business sectors. This particular sector is a consultancy and expertise service in various fields of science at ITS through collaboration with regional/ central governments, state/ private companies, and private institutions/ companies. As a center of professional collaboration administration service, BPPU has been greatly improving its professional collaboration service for 3 years However, when it comes to delivering professional collaboration services, the business sector receives the most complaints amongst others. The largest part of the complaints is about service speed and accuracy. In relation to that, BPPU management and staff are committed to improving the service quality that they deliver to BPPU customers, especially research teams/ professional collaboration practitioners. Therefore, it is required to conduct a study on analyzing the quality of Professional Collaboration service, so that BPPU can determine corrective and improvement actions. 
The $1^{\text {st }}$ International Conference on Business and Engineering Management (IConBEM 2020)

February $1^{\text {st }} 2020$, Institut Teknologi Sepuluh Nopember, Surabaya, Indonesia

Table 1.

Results of Validity and Reliability Tests on Research Variables

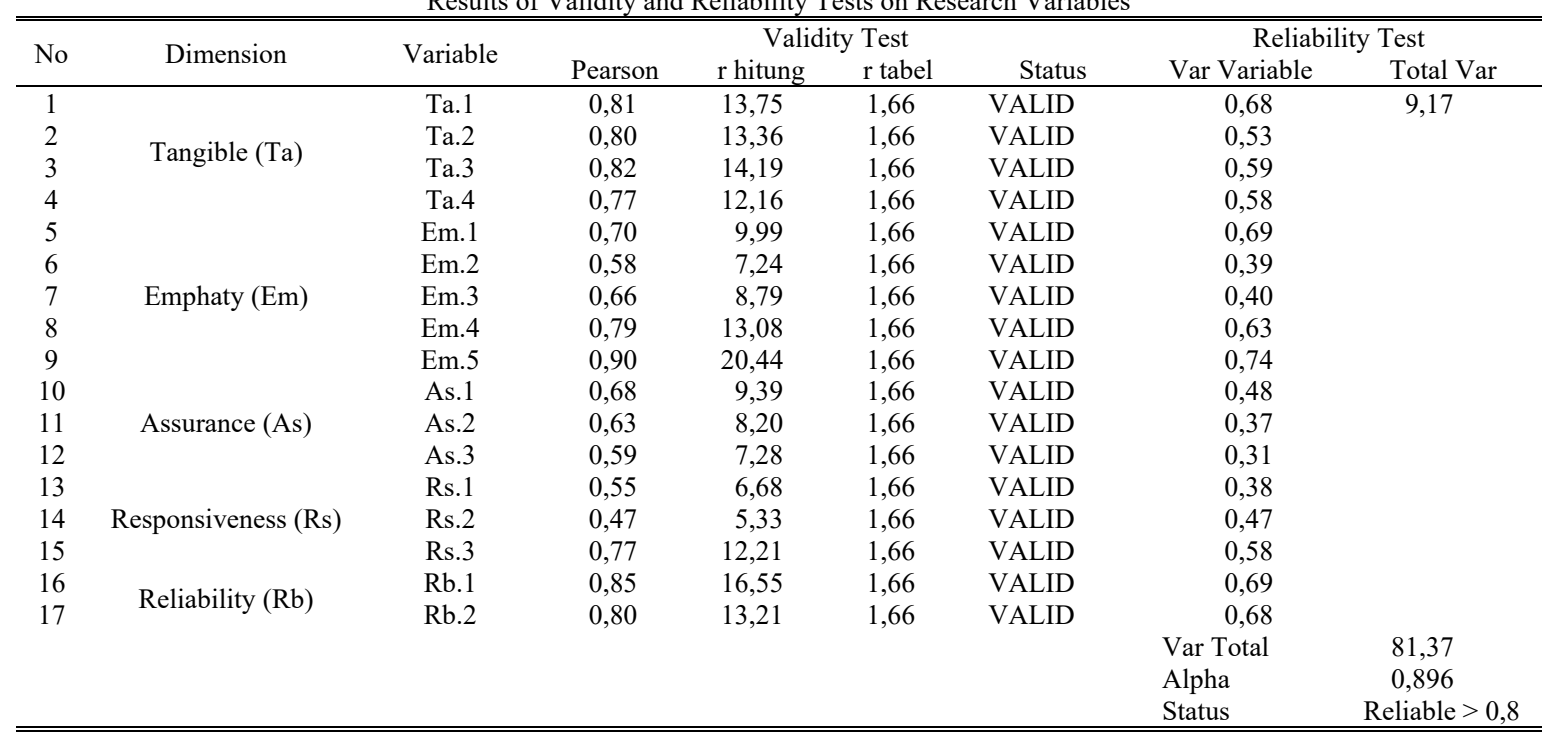

This research aims at analyzing gaps between perception of service quality and the expectations the customers have, so that BPPU can measure customer's satisfaction level about BPPU's service. Subsequently, BPPU can determine prioritized improvement steps in order to improve BPPU's service quality.

Scope of the study is analyzing the level of service quality at Professional Collaboration, especially BPPU customers who are practitioners, collaboration research team (team leader, team members, experts), or admin staff who actively work with BPPU to carry out professional collaborations in various fields of expertise with ITS partners such as regional government, central government, BUMN/BUMD, and national and international private institutions/ companies.

\section{METHOD}

The approach to this study adopts objects of the service of BPPU Professional Collaboration, with preliminary study in the forms of literature review and field study. A literature study is conducted to gather information related to Servqual, IPA, and QFD. Meanwhile, field study is administered to collect primary and secondary data related to the service of BPPU Professional Collaboration. Primary data is obtained by distributing the questionnaire to customers of BPPU Professional Collaboration as stated in the scope of the study, namely team leader/ members and administrative staff of practitioner team. The data gained from the questionnaire is the evaluation of customer perceptions and expectations about the service of the business sector, with the minimum number of samples is 90 respondents.

The questionnaire is designed according to Parasuraman Servqual, with variables of service quality which are categorized in 5 quality dimensions, i.e. TERRA - Tangible (Ta), Empathy (Em), Responsiveness (Rs), Reliability (Rb), and Assurance (Ra). There are 17 selected variables which are chosen based on previous researches and adjusted to the service condition at BPPU.
As stated previously, the methods used in this research are Servqual, Importance-Performance Analysis (IPA) and Quality Function Deployment (QFD). SERVQUAL is a service quality approach that was designed by Parasuraman. According to Parasuraman, there are 5 dimensions of service quality [2]. SERVQUAL approach is employed to measure the gaps between customer perception towards the service and customer expectations. Customer satisfaction is calculated by subtracting customer expectations by service quality.

According to Ruhimat (2008), IPA method is an easy application technique to arrange attributes of the level of importance and level of implementation itself which is useful for the development of effective marketing programs. IPA combines the measurement of factors of level of importance and level of satisfaction in a two-dimension graphic that makes it easy to explain the data and get practical suggestions. IPA graphic is divided into four quadrants.

Quality Function Deployment (QFD) is a structured method used in the process of product planning and development to determine specifications of customer needs and expectations, as well as systematically evaluating the capability of a product or service in meeting customer needs and expectations [3]. Data analysis begins with the validity and reliability tests to examine the dependability and consistency of the measuring instrument. Valid and reliable attributes are then analyzed. The data analysis steps in this research are as follows:

1) Conduct a descriptive analysis or frequency analysis to the servqual variables.

2) Carry out analysis using IPA method to get the factors that influence the results obtained in the Servqual model.

3) Integrate the result of Servqual and IPA analysis into the QFD method according to weighting customer needs and technical responses, which are the result of BPPU internal managerial discussion.

4) Construct strategies and recommendations for the Improvement Program of Service Quality of Collaboration. 
The $1^{\text {st }}$ International Conference on Business and Engineering Management (IConBEM 2020)

February $1^{\text {st }} 2020$, Institut Teknologi Sepuluh Nopember, Surabaya, Indonesia

Table 2 .

Result of Gap Servqual Analysis

\begin{tabular}{|c|c|c|c|c|c|}
\hline No & Dimension & Attibute Code & Perseption & Expectation & Gap \\
\hline 1 & & Ta. 1 & 3,228 & 4,020 & $-0,792$ \\
\hline 2 & Tangible & Та.2 & 3,653 & 4,178 & $-0,525$ \\
\hline 3 & (Ta) & Та.3 & 3,475 & 4,099 & $-0,624$ \\
\hline 4 & & Ta.4 & 3,505 & 4,059 & $-0,554$ \\
\hline 5 & & Em.1 & 2,911 & 4,208 & $-1,297$ \\
\hline 6 & & Em.2 & 2,842 & 4,366 & $-1,525$ \\
\hline 7 & $\begin{array}{c}\text { Empnaty } \\
\text { (Fm) }\end{array}$ & Em.3 & 3,317 & 4,317 & $-1,000$ \\
\hline 8 & $(E m)$ & Em.4 & 3,059 & 4,069 & $-1,010$ \\
\hline 9 & & Em.5 & 3,356 & 4,040 & $-0,683$ \\
\hline 10 & & As.1 & 3,574 & 4,267 & $-0,693$ \\
\hline 11 & $\begin{array}{l}\text { Assurance } \\
(A s)\end{array}$ & As. 2 & 3,594 & 4,307 & $-0,713$ \\
\hline 12 & $(A S)$ & As. 3 & 3,178 & 4,436 & $-1,257$ \\
\hline 13 & & Rs.1 & 3,317 & 4,386 & $-1,069$ \\
\hline 14 & Responsiveness (Rs) & Rs.2 & 2,416 & 4,416 & $-2,000$ \\
\hline 15 & & Rs.3 & 3,426 & 4,020 & $-0,594$ \\
\hline 16 & & Rb.1 & 3,208 & 4,050 & $-0,842$ \\
\hline 17 & Rellability (Rb) & $\mathrm{Rb} .2$ & 3,436 & 4,109 & $-0,673$ \\
\hline
\end{tabular}

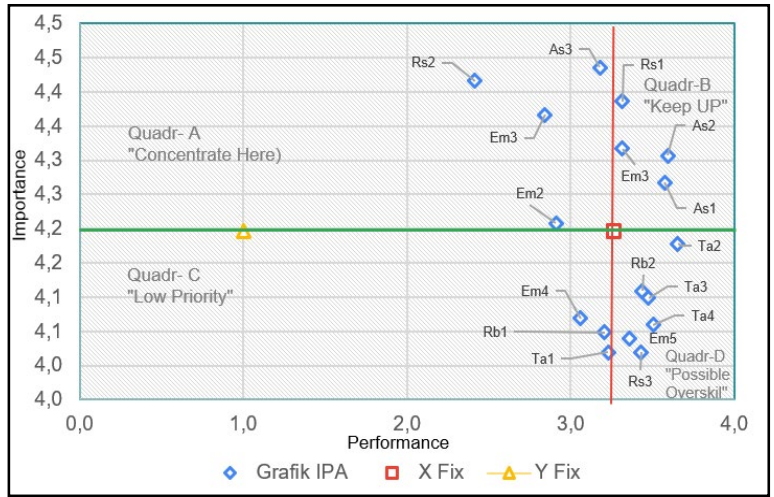

Figure 1. Cartesian Diagram of IPA.

\section{RESULTS AND DISCUSSION}

\section{A. Description of Respondents' Data}

The results of questionnaire data collection with 101 respondents, who serve as team leaders, experts, and administration staff, are as follows: $77.7 \%$ are male respondents and $33.3 \%$ are female respondents, with the positions of the respondents as team leader at $59.6 \%$ and admin staff at $40.4 \%$. As for the distribution of professional collaboration partner, the largest part is central/ regional government at $66.7 \%$, BUMN/ BUMD at $50.5 \%$, and private institutions/ companies at $40.4 \%$.

\section{B. Validity and Reliability Tests on the Questions of the Customer Satisfaction Questionnaire}

A validity test is conducted on every variable of the questions on the questionnaire. The coefficient of validity test can be measured by Pearson Product Moment r. R-count is compared to R-table at a significant degree of 5\%. If R-count is larger than R-table by $5 \%$, it means that the variable is valid. According to Suharsimi (2006), reliability test refers to an understanding an instrument is trustworthy as a data collection tool because the instrument is good, for alpha value $>0.80$. The results of validity and reliability tests on the questionnaire is shown in Table 1.

The validity results show that all variables are valid, because R-count is larger than R-table (1.66). Meanwhile, the reliability results display the alpha value as much as 0.896 or $99.6 \%$ which is greater than the alpha value $(80 \%)$. This implies that the questionnaire data is trustworthy to be used to analyze the research.

\section{Processing Service Quality (Servqual) Data}

The valid and reliable data is used for analyzing the gap by servqual to determine the level of difference between the perceptions received by the user of professional collaboration service and the desired expectations. The processing results of the gap analysis of professional collaboration services are displayed in Table 2.

Based on the servqual result analysis in table 2, all variables possess gaps between the service perceived by the customers (perceptions) and the service expected by the customers (expectations). A sequence of the largest gap between perception and expectations are as follows:

1) Rs.2 (the ability to provide swift (responsive) service towards customer's requests)

2) Em.2 (Comprehensive procedures)

3) Em.1 (Supporting staff understand specific needs)

4) As. 3 (The ability to provide trust of the accuracy of the management of professional collaboration)

This is consistent with what has been conveyed on the background of the study that there are complaints about the speed and accuracy in Professional Collaboration service.

\section{Analysis of Performance and Importance with IPA}

Based on the above servqual gap analysis, all variables of service of Professional Collaboration contain a gap between expectations and perceptions, but may not necessarily reflect what variables required by the customers. In order to get the required variables, IPA (Importance - Performance Analysis) comes in useful. This analysis serves as a method to distinguish required variables from those that have the lowest customer satisfaction level.

This analysis applies the Cartesian diagram which is divided into 4 (four) quadrans with the average limit of $\mathrm{X}$ and $\mathrm{Y}$ of $(3.26 ; 4.20)$ which are obtained from Cartesian diagram of IPA as shown on Figure 1.

The result of the quadrants grouping of IPA method shows positions for each service variable received by the customers. BPPU management, therefore, can design solutions to address the problems. The outcome of grouping service variables based on the quadrans is as shown on Figure 1. 
The $1^{\text {st }}$ International Conference on Business and Engineering Management (IConBEM 2020)

February $1^{\text {st }} 2020$, Institut Teknologi Sepuluh Nopember, Surabaya, Indonesia

Table 3.

Result of Gap Servqual Analysis

\begin{tabular}{lccccc}
\hline \hline \multicolumn{1}{c}{ Description } & IR & Sales Point & Weight & $\begin{array}{c}\text { Relative } \\
\text { Weight }\end{array}$ & Rank \\
\hline Supporting Staff understand specific needs & 1,446 & 1,50 & 9,12 & 22,4 & 4 \\
$\begin{array}{l}\text { Comprehensive procedure } \\
\text { The ability to provide swift (responsive) service }\end{array}$ & 1,537 & 1,50 & 10,06 & 24,8 & 2 \\
to customer's requests & 1,828 & 1,50 & 12,11 & 29,8 & 1 \\
$\begin{array}{l}\text { The ability to provide trust in the accuracy of the } \\
\text { management of Professional Collaboration }\end{array}$ & 1,396 & 1,50 & 9,29 & 22,9 & 3 \\
& & Total & 40,58 & 100 & \\
\hline \hline
\end{tabular}

\begin{tabular}{|c|c|c|c|c|c|c|c|c|c|}
\hline $\begin{array}{l}\text { Demanded Quality } \\
\text { (a.k.a. "Customer } \\
\text { Requirements" or } \\
\text { "Whats") } \\
\end{array}$ & 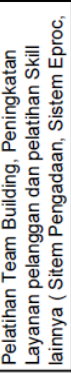 & 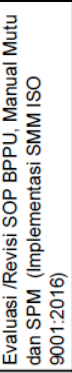 & 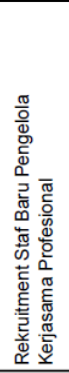 & 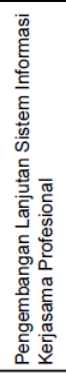 & 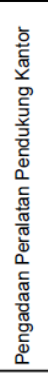 & 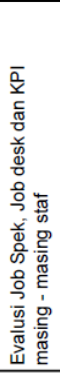 & 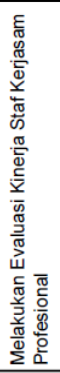 & 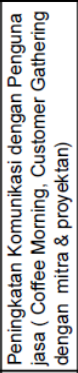 & 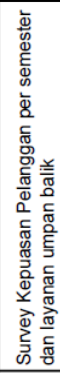 \\
\hline Staf pendukung memahami kebutuhan spesifik & 0 & & 0 & & & & 0 & $\boldsymbol{\Delta}$ & \\
\hline Kejelasan prosedur & & ○ & & ○ & & 0 & 0 & & \\
\hline $\begin{array}{l}\text { kemampuan memberikan layanan yang cepat } \\
\text { (responsif) atas permintaan pelanggan }\end{array}$ & 0 & 0 & 0 & ○ & 0 & $\boldsymbol{\Delta}$ & $\boldsymbol{\Delta}$ & & 0 \\
\hline $\begin{array}{l}\text { Kemampuan memberikan rasa } \\
\text { ketepatan pengelolaan kerjasam }\end{array}$ & 0 & $\boldsymbol{\Delta}$ & 0 & 0 & $\boldsymbol{\Delta}$ & 0 & 0 & 0 & 0 \\
\hline
\end{tabular}

Figure 2. Matrix of the Relationship between Whats and and Hows.

\section{1) Quadrant A (Concentrate Here)}

Quadran A of IPA diagram means that customer expectations towards the variables are high, but the performance/ perception towards the service given is fair or low. For that reason, the service variables in Quadran A must become BPPU's main priority to improve the satisfaction level of Professional Collaboration services. Variables included in Quadran A are as follows: staff's level of understanding about special needs in the administration of Professional Collaboration, comprehensive procedure, the ability to provide swift (responsive) service, the ability to provide trust of the accuracy of the management of professional collaboration.

\section{2) Quadrant B (Keep Up)}

Quadran B of IPA shows that customer expectations towards the variables are high and perceptions toward BPPU service are very high. Variables in Quadran B must be maintained by the company to prolong customer satisfaction and loyalty. Variables in this quadrant are available for consultation and meeting with collaboration partners, the ability to actively communicate with customers, BPPU staff and leader's honesty in providing services, as well as staff attentiveness and civility in delivering their services.

\section{3) Quadrant C (Low Priority)}

Quadrant $\mathrm{C}$ of the IPA diagram implies that customer expectation and perception towards BPPU services or performances are low. Thus, these attributes is of minor attention for customers, although the performance should still be improved by BPPU. Variables included in this area are unbiased (equal treatment) to all customers, accuracy and validity of data recording in Professional Collaboration documents, as well as the use of information technology.

1) Quadrant D ( Possible Overskill)
Quadrant D of the IPA diagram shows that the variables inside the quadrants are considered less important and excessive by the customers. In this manner, the performances of these variables in this quadrant should be reconsidered so that the company can determine its focus and optimize its performance. The result analysis represents that variables included in this quadrant are the ability of BPPU management and staff to provide clear and comprehensible information, cleanliness and comfort of the service room, appearance and neatness of BPPU staff, availability of comfortable and clean supporting facilities (meeting room, toilets, mosque, lobby), BPPU management and staff's ability to resolve critics/ complaints, service staff have reliable skills and knowledge.

\section{E. Analysis of the Selection of Development Strategy} Selection by Quality Function Deployment (QFD)

Based on the above IPA analyses, the variables in Quadrant A must receive more attention for improvement and solutions by BPPU management, as an effort to improve service quality for Professional Collaboration customers. In order to find the proper solution in improving the service quality, the researcher applies Quality Function Development (QFD).

\section{1) Classifying Customer Issue Based on Voice of Customer (WHATs Matrix)}

Determine customer issues based on voice of customer (WHATs matrix) which is in line with the result of IPA classification included in Quadrant A. Since variables in Quadrant A are considered of low performance and have high customer expectations, the selected customer issues are as follows: staff level of understanding about special needs on administration about Collaboration, comprehensive procedures, the ability to provide swift (responsive) service towards customer's requests, ability to provide trust of the accuracy of the management of professional collaboration. 
The $1^{\text {st }}$ International Conference on Business and Engineering Management (IConBEM 2020)

February $1^{\text {st }} 2020$, Institut Teknologi Sepuluh Nopember, Surabaya, Indonesia

Table 4.

Weight Relative Technical Response Analysis

\begin{tabular}{|c|c|c|c|}
\hline Technical Responses & $\begin{array}{c}\text { Weight Technical } \\
\text { total }\end{array}$ & $\begin{array}{r}\text { Relative Weight } \\
\text { Response Tech }\end{array}$ & Rank \\
\hline Human Resources Development (Training) & 360,5 & 16,23 & 2 \\
\hline $\begin{array}{l}\text { Evaluate/ Revise BPPU SOP, Quality Manual and Miminum Service } \\
\text { Specifications (SPM) }\end{array}$ & 335,6 & 15,11 & 3 \\
\hline New Staff Recruitment to Manage Professional Collaboration & 52,3 & 2,36 & 9 \\
\hline Advance Development of Information System & 560,4 & 25,23 & 1 \\
\hline Procurement of Office Equipments & 112,4 & 5,06 & 8 \\
\hline Job Spec/ Job Desc and KPI Evaluation & 172,9 & 7,78 & 5 \\
\hline Staff Performance Evaluation & 240,3 & 10,82 & 4 \\
\hline Improved Communication with Service Users & 228,4 & 10,28 & 5 \\
\hline \multirow[t]{2}{*}{ Conduct Customer Satisfaction Survey per Semester and feedback service } & 158,2 & 7,12 & 6 \\
\hline & & 100,000 & \\
\hline
\end{tabular}

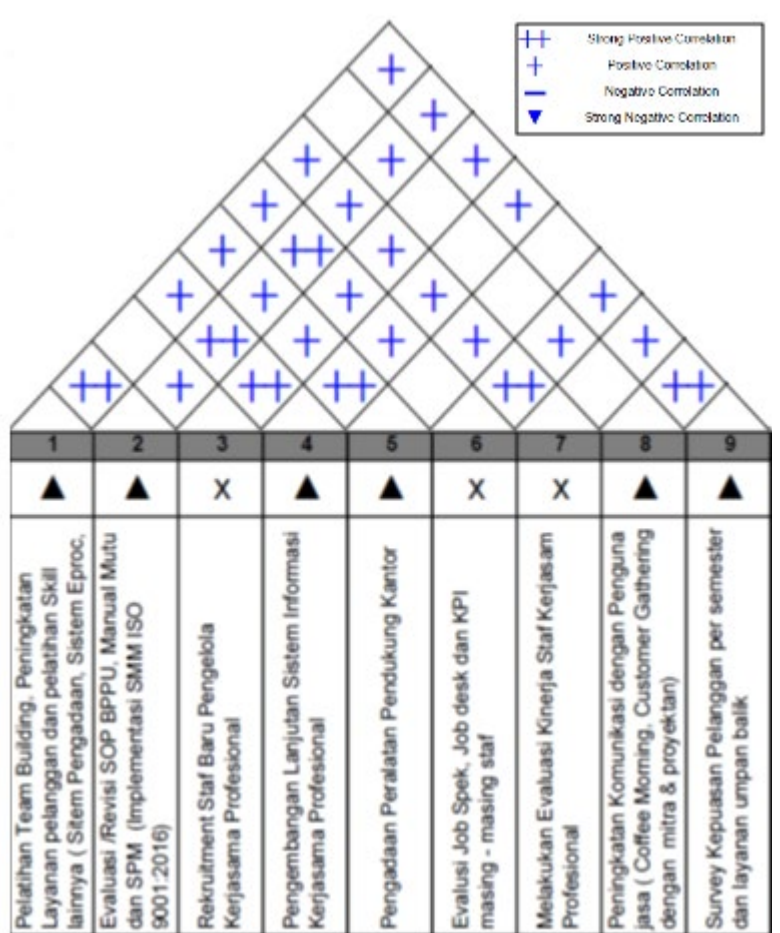

Figure 3. Correlation matrix between technical response (Hows).

\section{2) Creating Planning Matrix}

In estimating this planning matrix, the most important thing is to determine the relative weight ranking for variables related to customer requirement. The analysis process begins with mean data on the perceptions and expectations of the variables that have been determined as customer requirement. The next step is determining the Improvement Ratio (IR), Sales Points, Weight, and Relative Weight with results as shown in Table 3.

a.Listing Technical Descriptor/Response (Matrix Hows)

Technical engineering in the form of technical descriptor plays as BPPU Management responds. The technical response is gained through internal discussion with BPPU management team (heads of division, heads of sub-division, division coordinators, and several executor staff). The discussion and brainstorming session amongst BPPU management is conducted to respond to the voice of customer or Customer Requirements (What). The discussion results in the following 9 (nine) technical responses (How):

1. Training on Team Building, Customer Service Improvement, and other skill trainings (Procurement
System, Eproc System, Online Invoice, Sales Engineer, etc)

2. Evaluation/ Revision of BPPU SOP, Quality Manual and Minimum Service Specifications (SPM) (Implementation of SMM ISO 9001:2016)

3. Recruitment of New Staff for Managing Professional Collaboration

4. Advance Development of Information System at Professional Collaboration

5. Procurement of Office Supporting Equipments

6. Evaluate Job Specifications, Job Descriptions and KPI of each staff at BPPU

7. Evaluate Staff Performances at Professional Collaboration

8. Improved Communications with Practitioner Team (Coffee Morning sessions, Customer Gathering events both with partners or practitioners)

9. Conduct Customer Satisfaction Survey for each Semester and Feedback Service

b. Developing Relationship between Matrix Whats and Matrix Hows (Relationship Matrix)

Whats Matrix is the question and Matrix Hows the answer. This means that these two matrices have a specific relationship as shown in Figure 2. Each relationship between Whats and Hows has its own value.

c.Creating Relationship amongs Hows Matrix

Matrix Hows serves as an alternative answer to What's that consists of several questions. The relationship may support or contradict each other. Implementation of the policies agreed upon should consider this aspect. When the policies support each other, they will be beneficial for achieving a target. However, if the policies taken contradict each other, the result may become less fruitful. The result of the analysis of the relationship among variables in the Hows matrix done by BPPU Management Team is shown in Figure 3.

d. Develop House of Quality (HoQ) to determine the prioritized technical description

The result of HoQ parameter development is calculated in total HoQ matrix analysis. Then, the researcher measures relative weight as a basis for determining priority order of program development strategies and service improvement activities at Professional Collaboration. The measurement of relative weight technical response based on the value of relative weight of customer requirements and whats and technical responses is shown in table 4 .

According to the result of QFD analysis as shown on Table 4 , priority order for improving the service quality at 
The $1^{\text {st }}$ International Conference on Business and Engineering Management (IConBEM 2020)

February $1^{\text {st }} 2020$, Institut Teknologi Sepuluh Nopember, Surabaya, Indonesia

Professional Collaboration which is in line with relative weight values to respond to customer needs is as follows:

1) Advance Development of Information System at Professional Collaboration

2) Training on Team Building, Customer Service Improvement, and other skill trainings (Procurement System, Eproc System, Online Invoice, Sales Engineer, etc)

3) Evaluation/ Revision of BPPU SOP, Quality Manual and Minimum Service Specifications (SPM) (Implementation of SMM ISO 9001:2016)

4) Evaluate Staff Performances at Professional Collaboration

5) Improved Communication with Service Users (Coffee Morning sessions, Customer Gathering events both with partners or practitioners)

6) Recruitment of New Staff for Managing Professional Collaboration

7) Evaluate Job Specifications, Job Descriptions and KPI of each staff

8) Conduct Customer Satisfaction Survey for each Semester and Feedback Service

9) Procurement of Office Supporting Equipment

F. Development Strategies with BPPU Internal Management $B P P U$

The HoQ analysis result of QFD produces a priority order of technical responses that are in line with relative weight values. The priority order, as proposed in the revised proposal, must be confirmed to BPPU management. This confirmation to BPPU management aims at receiving suggestions on whether the technical responses are feasible on the next BPPU development program. Therefore, BPPU internal management conducts a discussion session. It involves the heads of division, heads of sub-divisions, and BPPU service coordinator, each of whom provided input related to the priority of the programs and activities development that were the result of HoQ analysis. From the discussion result, the priority order of program development strategies and future activities to respond to customer requirements is as follows:

1) Evaluate Job Specifications, Job Descriptions and KPI of each staff

2) Evaluate Staff Performances at Professional Collaboration

3) Evaluation/ Revision of BPPU SOP to Manage Professional Collaboration

4) Recruitment of New ICT Staff

5) Advance Development of Information System at Professional Collaboration

6) Procurement of Office Supporting Equipments (scanner, all in one printer, Laptop min $i 7$ gen 10, etc)

7) Training on Team Building, Customer Service Improvement, and other skill trainings (Procurement System, Eproc System, Online Invoice, etc)

8) Improved Communications with Practitioner Teams (Coffee Morning sessions, Customer Gathering events both with partners or practitioners)

9) Conduct Customer Satisfaction Survey for each Semester and Feedback Service

\section{IV.CONCLUSION}

From the Analysis of Service Quality Improvement at BPPU Professional Collaboration, the researcher draws the following conclusions:

1) Based on servqual analysis, there are gaps between perceived service quality and customer expectations; gap analysis shows 7 variables that have greater gaps from customer satisfaction level. This implies that customers of BPPU Professional Collaboration expect improvement on the following variables:

a) The ability to provide swift (responsive) service towards customer's requests

b) Comprehensive procedures

c) Supporting staff understand specific needs

d) The ability to provide trust in the accuracy of the management of professional collaboration

e) The ability to actively communicate with customers

f) Unbiased (equal treatment) to all customers

g) BPPU availability to meet ITS potential partners or administrative consultations with users.

2) Based on IPA analysis results, there are four levels of customer satisfaction. Those are Quadran A, service variables that must become BPPU main priority to improve service satisfaction level at Professional Collaboration; Quadran B, service variables that must be maintained by the company in delivering services, in order to maintain customer satisfaction and loyalty; Quadran C, service variables with less attention or of low priority for customers, although BPPU need to improve; and, Quadran D, a scope of area that requires performance reconsiderations to determine company's focus and to optimize performance.

3) In prioritizing improvement (technical response) in the formulation of BPPU service quality improvement strategies, top-priority variables have been set up. In QFD analysis, these variables are obtained from Quadrant A of IPA analysis, or referred to as customer requirement (Whats). The variables in this customer requirement (Whats) must get technical responses (Hows) from BPPU internal management for further analysis by House of Quality. The analysis sees correlation/ relationship among Whats and Hows, Weight Relative Hows, as well as Weight Technical Based on the analysis, the formulation of priority strategies for improving service quality in consonance with the relative weight technical responses as follows:

a) Advance Development of Information System at Professional Collaboration

b) Training on Team Building, Customer Service Improvement, and other skill trainings (Procurement System, Eproc System, Online Invoice, Sales Engineer, etc)

c) Evaluation/ Revision of BPPU SOP, Quality Manual and Minimum Service Specifications (SPM) (Implementation of SMM ISO 9001:2016)

d) Evaluate Staff Performances at Professional Collaboration

e) Improved Communication with Service Users (Coffee Morning sessions, Customer Gathering events both with partners or practitioners)

f) Recruitment of New Staff for Managing Professional Collaboration 
The $1^{\text {st }}$ International Conference on Business and Engineering Management (IConBEM 2020)

February $1^{\text {st }} 2020$, Institut Teknologi Sepuluh Nopember, Surabaya, Indonesia

g) Evaluate Job Specifications, Job Descriptions and KPI of each staff

h) Conduct Customer Satisfaction Survey for each Semester and Feedback Service

i) Procurement of Office Supporting Equipment

\section{V.REFERENCES}

[1] R. Jain, G. Sinha, and S. Sahney, "Conceptualizing service quality in higher education,” Asian J. Qual., vol. 12, no. 3, pp. 296-314, 2011.

[2] R. Lupiyoadi, Manajemen Pemasaran Jasa; Teori dan Praktek. Jakarta: Salemba Empat, 2006.

[3] L. Cohen, Quality function deployment : how to make QFD work for you. Reading, Massachusetts: Addison-Wesley, 1995. 